\title{
Efektivitas Infusum Daun Durian (Durio zibethinus) sebagai Anestesi Alami Ikan Lele (Clarias gariepinus)
}

\author{
Effectiveness of Durian Leaf (Durio zibethinus) Infusion as Natural Anesthesia of \\ Catfish (Clarias gariepinus)
}

\section{Candro Dea Bagaskara Super Yudhistira, *Taufik Budhi Pramono, Purnama Sukardi}

\author{
Program Studi Akuakultur, Fakultas Perikanan dan Ilmu Kelautan, Universitas Jenderal \\ Soedirman, Purwokerto, 53123, Indonesia \\ *Korespondensi: tb1pram@yahoo.com
}

\begin{abstract}
ABSTRAK
Bahan anestesi buatan atau alami sangat dibutuhkan dalam transportasi ikan hidup, karena ikan secara fisiologi harus tetap hidup dan sehat sampai tempat tujuan. Daun durian adalah merupakan salah satu bahan alami yang dapat digunakan sebagai anetesi dalam transport karena mengandung mengandung senyawa metabolit sekunder seperti saponin, tanin dan flavonoid. Tujuan dari penelitian ini yaitu untuk mengetahui konsentrasi efektif infusum daun durian sebagai anestesi ikan lele terhadap waktu induksi dan sedatif, profil glukosa darah dan sintasan. Ikan dengan berat rataan 185,62 $\pm 9,06 \mathrm{~g}$ dalam $3 \mathrm{~L}$ air dengan konsentrasi bahan anestesi daun durian yang berbeda digunakan untuk mengetahui status pingsan ikan. Rancangan acak lengkap dengan empat perlakuan (konsentrasi infusum daun durian 5\%, 15\%, 25\%, dan 35\%.) dan tiga ulangan digunakan dalam penelitian ini. Hasil dari penelitian ini menunjukkan bahwa konsentrasi terbaik yang diperoleh adalah 35\%, dengan waktu induktif 9 menit-19 detik dan waktu sedatif 1 menit-42 detik. Sintasan ikan lele pada perlakuan terbaik sebesar $88.89 \%$, dengan kadar glukosa darah sebesar 63,23 mg/dL.
\end{abstract}

Kata kunci: Ikan Lele; daun durian; anestesi alami; infusum,

\begin{abstract}
Artificial or natural anesthetic ingredients are needed in the transportation of live fish, because fish must be physiologically alive and healthy to their destination. Durian leaf is one of the natural ingredients that can be used as anesthetics in transport because it contains secondary metabolites such as saponins, tannins and flavonoids. The purpose of this study was to determine the effective concentration of durian leaf infusion as catfish anesthesia during transportation on induction and sedative time, blood glucose profile and survival rate. Fish with an average weight of $185,62 \pm 9,06 \mathrm{~g}$ in $3 \mathrm{~L}$ of water with different concentrations of durian leaf anesthetics are used to determine the status of fish fainting. A complete randomized design (CRD) with four treatments $(5 \%, 15 \%, 25 \%$, and $35 \%$ durian leaf infusion concentrations) and three replications were applied in this study. The results of this study indicated that the best concentration obtained was $35 \%$, with an inductive time of $9 \mathrm{~min} .19 \mathrm{sec}$. and a sedative time of $1 \mathrm{~min} .42 \mathrm{sec}$. The survival rate of catfish in the best treatment was $88.89 \%$, with a blood glucose level of $63.23 \mathrm{mg} / \mathrm{dL}$.
\end{abstract}


Keywords: Catfish; durian leaves; natural anesthesia; infusion

\section{PENDAHULUAN}

Ikan lele merupakan komoditas perikanan air tawar unggulan di Indonesia yang memiliki nilai ekonomis dan permintaan pasar yang tinggi (Arief et al., 2014; Saputra et al., 2017). Pemenuhan permintaan pasar tersebut perlu disiasati dengan peningkatan produksinya. Peningkatan produksi ikan lele sebagai komoditas unggulan sangat bergantung pada stok, tingkat produksi dan distribusi baik ukuran benih hingga induk dari suatu wilayah ke wilayah lain (Dobsikova, 2009; Saputra et.al., 2017). Distribusi ikan yang umum dilakukan adalah dengan sistem transportasi baik transportasi basah maupun kering (Soedibya dan Pramono, 2018).

Pendistribusian stok ikan lele perlu dilakukan dengan penanganan yang baik agar tidak mengalami stres fisik dan fisiologis yang tinggi (Mgbenka dan Ejiofor, 1998; Ogretmen dan Gokcek, 2013; Hastiadi et al., 2015), menjamin kualitas dan kelulushidupan sampai tujuan hingga pemeliharaan (Temitope, 2014). Hal ini mengingat ikan lele dari golongan catfish memiliki sifat pergerakan yang sangat aktif dan secara morfologi memiliki patil yang dapat berdampak pada kerusakan tubuh, bahkan kematian baik saat transportasi maupun beberapa waktu yang singkat dalam wadah budidaya. Pengurangan resiko akibat proses transportasi dapat dilakukan dengan penggunaan teknis anestesi atau pemingsanan (Septiarusli et al., 2012).

Teknik anestesi atau pemingsanan mampu mengurangi pergerakan serta menekan aktivitas metabolis-me ikan selama transport- tasi (Fazril, et al., 2017). Pemilihan bahan anestesi harus mempertimbangkan berbagai karakteristik seperti, mudah larut dalam air, waktu induksi dan pemulihan yang cepat, tidak meninggalkan residu bagi ikan, serta harga terjangkau dan cara perolehannya mudah (Saskia et al., 2012; Temitope, 2014). Bahan anestesi alami menjadi suatu alternatif dan pilihan yang tepat dibandingkan bahan kimia (Sukarsa, 2005). Teknik pemanfaatan bahan alami dapat dilakukan dengan menggunakan ekstrak (Mgbenka dan Ejiofor, 1998; Septiarusli et al., 2012) dan infusum (Abid et al., 2014).

Beberapa peneliti telah memanfaatkan bahan alami untuk anestesi alami untuk ikan seperti buah keben (Barringtonia asiatica) (Septiarusli et al., 2012), daun jambu (Psidium guajava) (Suwandi et al., 2013), ekstrak umbi teki (Hanum, 2014), daun picung (Pangium edule) (Munandar et al., 2017), ekstrak tembakau (Nicotinia tobacum) (Arlanda et al., 2018), daun bandotan (Ageratum conyzoides) (Sulmartiwi et al., 2013). Bahan alami yang berpotensi sebagai anestesi umumnya merupakan bahan-bahan yang mengandung senyawa metabolit sekunder seperti saponin dan rotenone (Kritzon, 2003; Zulfamy, 2013). Daun durian (Durio ziberthinus) juga mengandung senyawa tersebut dan dapat dijadikan sebagai bahan anestesi. Pemanfaatan infusum daun durian (Durio zibethinus) saat ini baru dilakukan pada ikan Nila (Abid et al., 2014), dengan waktu induksinya 40 menit dan waktu sedatif atau pemulihannya selama 48 menit, serta pada ikan bawal (Munandar et al., 2017), dengan waktu induksi tercepat 
selama 100 menit, dan waktu sedatif tercepat selama 1 menit 30 detik. Akan tetapi, pemanfaatan untuk anestesi pada ikan lele hingga saat ini belum pernah dilakukan. Maka dari itu penelitian ini diharapkan dapat mengetahui konsentrasi efektif berdasarkan waktu induksi, waktu sedatif, kadar glukosa darah, dan tingkat kelangsungan hidup ikan lele. Penelitian ini diharapkan dapat menjadi dasar dalam pengembangan teknik transportasi selanjutnya.

\section{MATERI METODE}

\section{Pelaksanaan penelitian}

Penelitian ini dilakukan pada bulan Februari 2020, di Laboratorium Hatchery dan Teknologi Akuakultur, Fakultas Perikanan dan Ilmu Kelautan, Universitas Jenderal Soedirman. Berat dan panjang rata-rata ikan lele sebagai ikan uji masing-masing berukuran 185,62 \pm 9,06 gram dan $29,23 \pm 0,98 \mathrm{~cm}$ yang diperoleh dari pembudidaya ikan di Purwokerto. Penelitian ini menggunakan metode eksperimental dengan Rancangan Acak Lengkap (RAL). Perlakuan yang dilakukan menggunakan konsentrasi larutan infusum daun durian yang berbeda yaitu, P1 (5\%), P2 (15\%), P3 (25\%) dan P4 (35\%) dengan masing-masing perlakuan diulang sebanyak 3 (tiga) kali.

\section{Pembuatan Larutan Infusum}

Larutan yang digunakan yaitu air dengan rebusan daun durian yang selanjutnya disebut sebagai infusum. Konsentrasi infusum dihitung berdasarkan Nuraini et al. (2016), yang didapat dari perhitungan hasil bagi antara berat daun durian (gram) dengan jumlah air yang digunakan sebagai media anestesi (mL) lalu dikalikan dengan $100 \%$. Daun durian yang ditimbang selanjutnya dipotongpotong kecil lalu direbus dengan 1 Liter aquades dalam suhu $\pm 90^{\circ} \mathrm{C}$.

\section{Pengamatan waktu induksi dan pemulihan dari proses anesstesi}

Ikan lele yang akan diuji, dipelihara terlebih dahulu selama 3 hari dan dipuasakan selama 24 jam sebelum perlakuan. Ikan uji dimasukkan ke dalam media air pengangkutan sebanyak 3 liter yang telah berisi larutan infusum daun durian sesuai dengan konsentrasi yang telah ditentukan. Perhitungan waktu induktif ikan uji dihitung berdasarkan waktu saat awal ikan diletakkan pada media anestesi, hingga ikan mengalami pingsan immotilitasi. Sedangkan perhitungan waktu sedatif (waktu sadar) ikan lele dengan menghitung waktu saat ikan mulai diletakkan pada media air dengan aerasi hingga ikan mulai mengalami pergerakkan. Waktu induktif dan sedatif dihitung dalam satuan waktu menit-detik. Selama proses induksi dan pemulihan diamati pula status fisiologi akibat anestesi yang mengacu pada Theinpoint dan Niemegeers (1965) (Tabel 1). Selain itu dilakukan pengamatan secara deskriptif tingkah laku atau respon morfologis dan ketahanan ikan selama pembiusan menggunakan konsentrasi infusum yang berbeda. 
Tabel 1. Tingkatan anestesi dan recovery.

\begin{tabular}{cl}
\hline Tingkat Induksi & \multicolumn{1}{c}{ Deskripsi } \\
\hline I-I & $\begin{array}{l}\text { Kehilangan keseimbangan } \\
\text { Kehilangan gerakan tubuh tetapi gerakan operculum } \\
\text { masih ada } \\
\text { I-II }\end{array}$ \\
I-III & Tehilangan gerakan tubuh dan operculum secara total \\
\hline Tingkat Recovery & \\
\hline R-I & $\begin{array}{l}\text { Gerakan tubuh dan operculum mulai aktif } \\
\text { R-II }\end{array}$ \\
R-III & \begin{tabular}{l} 
aneseimbangan mulai kembali dan penampilan seperti pra- \\
\hline
\end{tabular}
\end{tabular}

\section{Pengukuran Analisis Glukosa Darah}

Pengukuran kadar gula darah dilakukan sebelum perlakuan anestesi dan setelah perlakuan. Uji glukosa darah pada penelitian ini menggunakan alat GlucoDr AGM 2100 yang merupakan alat portabel dan dapat digunakan untuk mengukur kadar gula darah, hasilnya dapat diketahui dalam waktu 11 detik. Tes strip dimasukkan ke dalam port tes, lalu ditempelkan pada darah yang diuji. Sampel darah minimal yang dibutuhkan untuk mengukur kadar gula darah yaitu sebanyak $4 \mu \mathrm{L}$. Hasil tes kemudian ditampilkan pada layar LCD secara otomatis, meter GlucoDr akan menampilkan hasil kadar gula darah dalam rentang $30-600 \mathrm{mg} / \mathrm{dL}$. Uji ini dilakukan sebelum diberi larutan anestesi dan setelah proses pembugaran atau pemulihan (Roohi dan Imanpoor, 2015).

\section{Tingkat Kelangsungan Hidup}

Perhitungan tingkat kelangsungan hidup dilakukan saat proses anestesi dan pasca pemulihan yang dilakukan selama 3 hari pemeliharaan. Menurut Effendie (1978) kelangsungan hidup ikan dapat dihitung dengan rumus:
$\mathrm{SR}=\frac{\text { Jumlah Ikan Hidup }}{\text { Jumlah penebaran awal }} \times 100 \%$

\section{HASIL DAN PEMBAHASAN}

\section{Waktu Induktif dan Sedatif}

Hasil uji statistik menunjukkan bahwa perlakuan konsentrasi infusum daun durian terhadap waktu induktif berbeda nyata $(\mathrm{P}<0,05)$. Rerata waktu induktif tercepat terdapat pada konsentrasi $35 \%$ dengan waktu 9 menit-19 detik dan terlama pada konsentrasi $5 \%$ dengan waktu 72 menit. Pada penelitian ini menunjukkan bahwa waktu induksi semakin cepat seiring peningkatan konsentrasi infusum daun durian. Kondisi serupa juga ditunjukkan pada penelitian (Mbgenka dan Ejiofor 1998; Septiarusli et al., 2012; Abid et al., 2014; Munandar et al., 2017). Abid et al. (2014), melaporkan bahwa anestesi ikan lele menggunakan konsentrasi infusum durian antara 1300, 1700, 2300 ppm dalam $10 \mathrm{~L}$ air waktu induktifnya lebih dari 60 menit, sedangkan konsentrasi 3100 , 4100 dan 5100 ppm dalam $10 \mathrm{~L}$ air waktu induktifnya masing-masing yaitu 52, 45 dan 25 menit. Penelitian Saputra et al. (2017), juga melaporkan bahwa waktu induktif ikan lele yang dianestesi dengan ekstrak rebung bambu (Gigantochloa 
nigrociliata) berkisar antara 20-30 menit. Akan tetapi berbeda halnya dengan Teixeira et al. (2019), ikan lele yang dianestesi menggunakan agen anestesi kimia MS-222 memiliki rentang waktu induktif yang sangat cepat yaitu 4,5- 8 menit. Perbedaan waktu induksi antara bahan anestesi alami dan kimia diduga sangat terkait dengan belum diperolehnya ekstrak murni dan dosis yang tepat serta aman bagi ikan.

Menurut Aini et al. (2014), waktu yang ideal untuk memingsankan ikan adalah kurang dari 5 menit. Lamanya waktu induktif infusum daun durian dalam penelitian ini diduga karena adanya alat pernafasan tambahan (aborescent) pada ikan lele. Tingkatan waktu induktif dari proses anestesi berdasarkan Theinpoint dan Niemegeers (1965), masuk kategori tingkatan ke3 (I-3), yang mana ikan lele kehilangan gerakan tubuh dan operculum secara total. Berdasarkan hasil penelitian ini menandakan bahwa bahan infusum daun durian masuk dalam kriteria efikasi dan efektif dalam memingsankan. Soedibya dan Pramono (2018) menyatakan bahwa bahan anestesi, ukuran, umur dan jenis ikan sangat mempengaruhi kecepatan waktu pingsan.
Waktu sedatif atau pemulihan ikan lele hasil dari proses anestesi dengan infusum daun durian dalam penelitian ini menunjukkan tidak ada perbedaan nyata antar perlakuan $(P>0,05)$. Rerata waktu sedatif atau waktu pemulihan berada pada rentang 43 detik sampai dengan 1 menit-56 detik. Status fisiologis berdasarkan tingkatan waktu sedatif atau recovery menurut Theinpoint dan Niemegeers (1965), keempat perlakuan pada penelitian ini masuk dalam kriteria efektif waktu recovery (R3). Aini $e t$ al. (2014) menyatakan bahwa waktu sedatif atau pemulihan ikan yang ideal adalah kurang dari 4 menit. Semua perlakuan pada penelitian ini masuk dalam kriteria yang efektif. Kondisi serupa terdapat pada penelitian Munandar et al. (2017) yang menggunakan daun durian pada ikan bawal dengan waktu sedatif berada pada rentang 1,5-1,75 menit. Akan tetapi, berbeda halnya pada penelitian Hasan et al. (2016) yang menggunakan ekstrak biji karet dengan waktu sedatif berada pada rentang 26,33-40,67 menit. Waktu sedatif atau pemulihan dipengaruhi oleh konsentrasi infusum yang digunakan, tingginya penyerapan senyawa metabolit (Abid et.al., 2014).

Tabel 2. Rerata waktu induktif dan sedatif ikan lele yang dianestesi dengan infusum daun durian $(\mathrm{n}=3 ; \bar{x} \pm \mathrm{SD})$

\begin{tabular}{ccc}
\hline Perlakuan $(\%)$ & Waktu induktif (menit) & Waktu sedatif (menit) \\
\hline 5 & $72 \pm 1^{\mathrm{a}}$ & $0,83 \pm 0,28^{\mathrm{a}}$ \\
15 & $60,43 \pm 2,22^{\mathrm{b}}$ & $0,72 \pm 0,25^{\mathrm{a}}$ \\
25 & $23,37 \pm 0,58^{\mathrm{c}}$ & $1,94 \pm 0,51^{\mathrm{a}}$ \\
35 & $9,32 \pm 3,28^{\mathrm{d}}$ & $1,77 \pm 0,75^{\mathrm{a}}$ \\
\hline
\end{tabular}

Keterangan: Angka yang diikuti huruf kecil superscript yang berbeda menunjukkan perbedaan signifikan $(\mathrm{P}<0,05)$. 
Tingkat penyerapan senyawa metabolit bahan anestesi sangat bergantung pada kandungan lemak dan kondisi darah di jaringan (Soedibya dan Pramono, 2018). Faktor yang berpengaruh dalam pemulihan yaitu bergantung kecukupan oksigen dan kemampuan ikan untuk membersihkan bahan pembius dari dalam tubuhnya (Aprillia, 2017).

\section{Respon Morfologis Saat Anestesi}

Pengamatan respon morfologis ikan lele yang dianestesi dengan berbagai konsentrasi infusum daun durian dilakukan dengan merekam aktivitas mulai dari awal pemberian larutan infusum hingga ikan lele pingsan. Data respon morfologis ikan lele secara deskriptif tersajikan pada Tabel 3.

Respon ikan lele secara morfologi dan tingkah laku pada perlakuan beberapa konsentrasi infusum daun durian menunjukkan pola aktifitas yang sama yaitu dari pergerakan aktif kemudian melambat, mengalami hilang keseimbangan, stationer di dasar hingga mengalami pingsan. Waktu pingsan berbeda untuk masing-masing perlakuan (Tabel 3).

Konsentrasi $35 \%$ menunjukkan kondisi pingsan lebih cepat, kemudian diikuti konsentrasi $25 \%$, $15 \%$ dan 5\%. Hal ini diduga disebabkan interaksi senyawa metabolit sekunder saponin pada infusum daun durian dengan sel darah merah yang menghambat pengikatan, penyerapan dan pertukaran oksigen pada filamen insang hingga ikan mengalami gangguan pada system syaraf dan hilangnya keseimbangan. Hal ini sesuai dengan yang disampaikan oleh Seeman (1967) yang menyatakan bahwa senyawa saponin dapat mempengaruhi keseimbangan otak dan mengganggu sistem syaraf serta mengakibatkana hemolisis sel darah merah. Nur'aini (2014) memperkuat bahwa ikatan senyawa saponin dengan sel darah merah dapat menyebabkan terhambatnya proses respirasi pada ikan, sehingga gerakan operculum melambat. Senyawa metabolit saponin dari infusum daun durian ini menunjukkan adanya kinerja dan interaksi melalui impuls syaraf yang menghambat terkirimnya ion natrium ke gerbang ion natrium pada membran syaraf yang pada akhirnya metabolism mengalami penurunan (Stoskopf, 1993) dan menurunkan kerja otak serta membuat lumpuh system syaraf motorik $(\mathrm{Hu}, 2001)$.

\section{Tingkat Kelangsungan Hidup}

Tingkat kelangsungan hidup ikan lele pada penelitian ini telah dihitung 3 hari pasca anestesi infusum daun durian di wadah pemeliharaan budidaya (Tabel 4). Hasil uji statistik menunjukkan bahwa perbedaan perlakuan konsentrasi infusum daun durian tidak berpengaruh nyata terhadap tingkat kelangsungan hidup ikan lele $(\mathrm{P}>0,05)$.

Tingkat kelangsungan hidup pada penelitian ini berada pada rentang 77,78-100\%. Namun, penelitian ini menunjukkan hasil yang lebih baik jika dibandingkan dengan penelitian Abid et.al. (2014), yang melaporkan bahwa kelangsungan hidup ikan lele setelah mendapatkan perlakuan anestesi infusum dan ditransportasikan selama 8 jam berkisar 22.22-88.89\%. 
Tabel 3. Respon tingkah laku dan morfologi ikan lele yang dianestesi dengan infusum daun durian selama penelitian.

\begin{tabular}{|c|c|c|c|c|}
\hline \multirow{2}{*}{$\begin{array}{l}\text { Waktu } \\
\text { (Menit) }\end{array}$} & \multicolumn{4}{|c|}{ Perlakuan } \\
\hline & $5 \%$ & $15 \%$ & $25 \%$ & $35 \%$ \\
\hline $0-5$ & $\begin{array}{l}\text { Pergerakkan } \\
\text { aktif }\end{array}$ & $\begin{array}{l}\text { Pergerakkan } \\
\text { aktif }\end{array}$ & $\begin{array}{l}\text { Pergerakkan } \\
\text { melambat dan } \\
\text { kehilangan } \\
\text { keseimbangan }\end{array}$ & $\begin{array}{l}\text { Pergerakkan } \\
\text { melambat dan } \\
\text { kehilangan } \\
\text { keseimbangan }\end{array}$ \\
\hline $6-10$ & $\begin{array}{l}\text { Pergerakkan } \\
\text { melambat }\end{array}$ & $\begin{array}{l}\text { Pergerakkan } \\
\text { melambat dan } \\
\text { kehilangan } \\
\text { keseimbangan }\end{array}$ & $\begin{array}{l}\text { Stasioner di } \\
\text { dasar }\end{array}$ & Pingsan \\
\hline $11-15$ & $\begin{array}{l}\text { Stasioner di } \\
\text { dasar }\end{array}$ & $\begin{array}{l}\text { Stasioner di } \\
\text { dasar }\end{array}$ & Pingsan & \\
\hline $16-20$ & Pingsan & Pingsan & & \\
\hline $20-80$ & & & & \\
\hline
\end{tabular}

Tabel 4. Tingkat kelangsungan hidup ikan lele selama 3 hari pemeliharaan dalam wadah budidaya pasca anestesi infusum daun durian.

\begin{tabular}{cc}
\hline Perlakuan $(\%)$ & Tingkat Kelangsungan Hidup (\%) \\
\hline 5 & $100^{\mathrm{a}}$ \\
15 & $88,89^{\mathrm{a}}$ \\
25 & $77,78^{\mathrm{a}}$ \\
35 & $88,89^{\mathrm{a}}$ \\
\hline
\end{tabular}

Keterangan : Angka yang diikuti huruf kecil superscript yang berbeda menunjukkan perbedaan signifikan $(\mathrm{P}<0,05)$.

Penelitian lainnya, kelangsungan hidup ikan lele yang dianestesi dengan ekstrak rebung bambu hanya mencapai 60-78\% (Saputra et.al., 2017). Sedangkan penelitian Teixeira et al. (2019) yang menggunakan agen anestesi kimia MS-222 pada ikan lele memiliki rentang tingkat kelangsungan hidup yang lebih rendah yaitu antara 20-30\%. Hal ini menegaskan bahwa bahan alami seperti daun durian dengan menggunakan metode infusum memiliki potensi untuk dikembangkan sebagai bahan anestesi.
Salah satu faktor penyebab tingginya kelangsungan hidup ikan lele yaitu memiliki alat bantu pernafasan yang disebut aborescent. Menurut Ahmadi (2012) aborescent menjadi alat pernafasan tambahan yang mampu membuat ikan lele mengambil oksigen langsung dari udara. Terbukti pada perlakuan konsentrasi ringan (5\%) infusum daun durian yang diterapkan, ikan lele dapat bertahan dalam waktu yang cukup lama. Peningkatan konsentrasi infusum daun durian menyebabkan terjadinya penurunan yang fluktuatif 
dalam kelangsungan hidup pada ikan lele selama 3 hari pemeliharaan pasca perlakuan anestesi. Hal ini dapat disebabkan karena terhambatnya pengikatan oksigen dalam pembuluh darah yang berlebihan membuat ikan kehilangan kesadaran berlebih, dan membutuhkan upaya lebih untuk membersihkan kandungan metabolit daun durian dalam tubuhnya. $\mathrm{Hu}$ (2001) juga menambahkan bahwa interaksi bahan anestesi dengan system syaraf dapat menurunkan kerja otak akibat asupan oksigen yang kurang.

Kondisi ini serupa dengan apa yang disampaikan oleh Septiarusli et al. (2012) bahwa saponin sebagai salah satu zat metabolit sekunder memiliki kemampuan untuk memingsankan ikan, akan tetapi dapat bersifat toksik terhadap hewan berdarah dingin dan menghancurkan sel darah merah. Saputra et.al., (2107) menegaskan bahwa akibat interaksi bahan anestesi dengan berbagai konsentrasi ikan akan mengalami shock dan berpotensi mengakibatkan kematian. Hal tersebut disebabkan karena asam laktat darah mengalami peningkatan.

\section{Kadar Glukosa Darah}

Pengujian kadar glukosa darah dilakukan sebelum perlakuan dan setelah ikan dipulihkan kembali. Rerata kadar glukosa darah sebelum diberi perlakuan berada pada rentang 61,67 mg/dL - 70,33 mg/dL, sedangkan rerata kadar glukosa darah setelah pemulihan berada pada rentang $101 \mathrm{mg} / \mathrm{dL}-130 \mathrm{mg} / \mathrm{dL}$ (Tabel 5). Hasil uji statistik menunjukkan bahwa perbedaan perlakuan dalam konsentrasi infusum daun durian terhadap kadar glukosa darah ikan lele tidak berbeda nyata $(\mathrm{P}>0,05)$.
Rerata kadar glukosa darah setelah pemulihan pada penelitian ini $(101-130 \mathrm{mg} / \mathrm{dL})$ masih tergolong dalam kondisi yang bisa ditolerir dan tergolong rendah jika dibandingkan dengan penelitian Aprilia (2017) dengan rentang 129-187 mg/dL. Tingginya kadar glukosa juga terjadi pada penelitian Lepic et al. (2014) yang menggunakan anestesi berbahan kimia, seperti MS-222, 2phenoxyethanol untuk anestesi ikan Vimba Bream, Vimba Vimba. bahwa kadar glukosa darah setelah proses anestesi berada pada rentang 85-200 $\mathrm{mg} / \mathrm{dL}$. Porchas et al., (2009) mengemukakan bahwa pemberian anestesi pada ikan salah satu tujuannya adalah untuk mengurangi peningkatan stress dan kadar glukosa. Akan tetapi, pemberian anestesi untuk mengurangi stress sangat bergantung pada bahan anestesi, ukuran, umur dan jenis ikan (Soedibya dan Pramono, 2018).

Berdasarkan hasil yang dilakukan pada penelitian ini menunjukkan terjadinya kenaikan glukosa darah dari setiap perlakuan (Tabel 5). Kondisi ini menunjukan bahwa ikan. Selisih kadar glukosa darah tertinggi sebelum perlakuan dibanding setelah perlakuan terdapat pada perlakuan dengan konsentrasi $35 \%$ dengan selisih $63,23 \mathrm{mg} / \mathrm{dL}$, sedang selisih terendah terdapat pada perlakuan dengan konsentrasi $15 \%$ dengan selisih 33,67 mg/dL. Hal ini menunjukan bahwa ikan lele melakukan respon secara fisiologis terhadap berbagai konsentrasi perlakuan infusum daun durian sebagai upaya homeostasis atau mencapai titik keseimbangan kembali. Senada dengan yang disampaikan oleh Li et.al. (2009) yang menyatakan bahwa kadar glukosa merupakan penanda efek sekunder dari stress selain 
hormon kortikosteroid dan katekolamin. Enriquez et al. (2009), juga menambahkan bahwa perubahan kadar glukosa dalam darah secara fisiologis untuk mengatasi stress diatur pada poros hipotalamuspituitari-interrenal (HPI-Axis). Peningkatan kadar glukosa darah ini merupakan upaya ikan untuk menghasilkan energi yang cukup untuk menyeimbangkan kondisi fisiologis (Inoue dan Moraes, 2006; Li et.al., 2009).

\section{KESIMPULAN}

Infusum daun durian dengan konsentrasi 35\% menjadi konsentrasi yang paling efektif berdasarkan masa induksinya dengan waktu 9 menit-19 detik, masa sedatifnya dengan waktu 1 menit-46 detik, selisih kenaikan glukosa darahnya sebesar 63,23 $\mathrm{mg} / \mathrm{dL}$, dan tingkat kelangsungan hidup sebesar $88,89 \%$.

Tabel 5. Rerata kadar glukosa darah ikan lele sebelum dan sesudah dianestesi dengan infusum daun durian.

\begin{tabular}{ccccc}
\hline \multirow{2}{*}{ Perlakuan } & \multicolumn{3}{c}{ Nilai Glukosa Darah $(\mathrm{mg} / \mathrm{dL})$} & $\begin{array}{c}\text { Rata-rata normal } \\
\text { (Bittencourt } e t \\
\text { al., 2003) }\end{array}$ \\
\hline $5 \%$ & $70,33 \pm$ & Sesudah & Selisih & \\
$15 \%$ & $16,77^{\mathrm{a}}$ & $113,67 \pm 23,54^{\mathrm{a}}$ & 43,34 & \\
& $67,33 \pm$ & $101 \pm 23,81^{\mathrm{a}}$ & 33,67 & \\
$25 \%$ & $13,50^{\mathrm{a}}$ & & & $22,8-150$ \\
$35 \%$ & $61,67 \pm$ & $101,33 \pm 26,01^{\mathrm{a}}$ & 39,66 & \\
& $10,59^{\mathrm{a}}$ & & & \\
\hline
\end{tabular}

\section{DAFTAR PUSTAKA}

Abid, M.S., Masithah, E. D.m dan Prayogo. 2014. Potensi Senyawa Metabolit Sekunder Infusum Daun Durian (Durio zibethinus) Terhadap Kelulushidupan Ikan Nila (Oreochromis niloticus) Pada Transportasi Ikan Hidup Sistem Kering. Jurnal Ilmiah Perika-nan dan Kelautan 6 (1): 93-99.

Ahmadi, H., Iskandar, \& Kurniawati, N. 2012. Pemberian Probiotik dalam Pakan terhadap Pertumbuhan Lele Sangkuriang (Clarias gariepinus) Pada Pendederan II. Jurnal Perikanan dan Kelautan, 3(4): 99-107.
Aini, M., Ali, M, dan Putri, B. 2014. Penerapan Teknik Imotilisasi Benih Ikan Nila (Oreochromis niloticus) Menggunakan Ekstrak Daun Bandotan (Ageratum conyzoides) Pada Transportasi Basah. E-Jurnal Rekayasa dan Teknologi Budidaya Perairan, 2(2): 217-226.

Aprillia, B. 2017. Penggunaan Ekstrak Kasar Daun Pala (Myristica fragans houtt) Sebagai Anestesi Pada Simulasi Transportasi Ikan Mas (Cyprinus carpio). Skripsi. Bogor: Fakultas Perikanan dan Ilmu Kelautan, Institut Pertanian Bogor. 
Arief, M., Fitriani, N., dan Subekti, S. 2014. Pengaruh Pemberian Probiotik Berbeda pada Pakan Komersial Terhadap Pertumbuhan dan Efisiensi Pakan Ikan Lele Sangkuriang (Clarias sp.). Jurnal Ilmiah Perikanan dan Kelautan, 6(1): 49-53. http://dx.doi.org/10.20473/jipk. v6i1.11381

Arlanda, R., Tarsim., UTomo, D.SC. 2018. Pengaruh Pembrian Ekstrak Tembakau (Nicotiana tobacum) sebagai Bahan Anestesi Terhadap Kondisi Hematologi Ikan Nila (Oreochromis niloticus). Jurnal Sains Teknologi Akuakultur 2 (2): 32-40.

Bittencourt, L.R., Molinari, L.M., Scoaris, D.O., Pedroso, R.B., Nakamura, C.V., UedaNakamura1, T., Filho, B.A.A., and Filho, B.P.D. 2003. Haematological And Biochemical Values for Nile Tilapia Oreochromis niloticus Cultured In Semi-Intensive System. Acta Scientiarum, 2(25): 385-389

Dobsikova, R., Svobodova, Z., Blahova, J., Modra, H., and Velisek, J. 2009. The Effect of Transport on Biochemical and Haetological Indices of Common Carp (Cyprinus carpio L.). Journal of Animal Science. p. 510-518.

Effendi. 1978. Biologi Perikanan. Yayasan Pustaka Nusantara, Yogyakarta

Fazril S., Sukardi, Eri S., dan Mahendra. 2017. Efektifitas Konsentrasi Ekstrak Rebung Bambu (Gigantochloa nigrociliata) Sebagai Anestesi Terhadap Kelangsungan Hidup Benih Ikan Lele Sangkuriang
(Clarias gariepinus). Jurnal Akuakultura, 1(1) : 9-18

Hanum K. 2014. Penggunaan Ekstrak umbi teki (Cyperus rotundus 1.) sebagai bahan anestesi ikan bawal air tawar (Colossoma macropomum).

[Skripsi]. Bogor: Fakultas Perikanan dan Ilmu Kelautan, Institut Pertanian Bogor.

Hasan, H., Eka I.R. dan Bobi H. 2015. Pemanfaatan Ekstrak Biji Buah Keben (Baringtonia asiatica) Dalam Proses Anestesi Pada Transportasi Sistem Tertutup Calon Induk Ikan Mas (Cyprinus carpio). Jurnal Ruaya, 5: 29-32.

Hastiadi, H., Eka, I. R., dan Bobi, H. 2015. Pemanfaatan Ekstrak Biji Buah Keben (Barringtonia asiatica) Dalam Proses Anestesi Pada Transportasi Sistem Tertutup Calon Induk Ikan Mas (Cyprinus carpio). Jurnal Ruaya, 5 : 29-32. http://dx.doi.org/10.29406/rya. $\underline{\mathrm{vi} 1.497}$

Kritzon, C. 2003. Fishing With Poison. The Bulletin of Primitive Technology. School of North America. America. 25 $\mathrm{p}$.

Lepic, P., A. Stara., J. Turek., P. Kozak., J. Velisek. 2014. The Effects of Four Anaesthetics on Haematological and Blood Biochemical Profiles In Vimba Bream, Vimba Vimba. Veterinarni Medicina, 59(2): 81-87.

Mgbenka, B.O., and Ejiofor, E.N. 2013. Effects of Extracts of Dried Leaves of Erythrophleum suaveolens as Anesthetics on Clariid Catfish. Journal of Applied Aquaculture, 8(4): 73- 
80. https://doi.org/10.1300/J0 28v08n04_09

Munandar, A., Habibi, G. T., Haryati, S., dan Syamsunarno, M. B. 2017. Efektivitas infusum daun durian (Durio zibethinus) sebagai anestesi alami ikan bawal air tawar (Colossomama cropomum). Jurnal Ilmu-Ilmu Perairan, Pesisir dan Perikanan, 1(6): 1-8, https://dx. doi.org/10.13170/depik.6.1.592 $\underline{6}$

Nur'aini, M. 2016. Anestesi Ikan Mas (Cyprinus carpio) Dengan Ekstrak Daun Sirih Hijau (Piper betle) Pada Simulasi Transportasi. Laporan Penelitian. Institut Pertanian Bogor. 37 hal.

Öğretmen, F., and Gökçek, K. 2013. Comparative Efficacy of Three Anesthetic Agents on Juvenile African Catfish, Clarias gariepinus. Turkish Journal of Fisheries and Aquatic Sciences, 13: 51-56. http://dx.doi.org/ 10.4194/1303-2712-v13_1_07

Porchas, M. M., Cordova, L. R. M., Enriquez R. R. 2009. Cortisol and Glucose: Reliable Indicators of Fish Stress. PanAmerican Journal of Aquatic Sciences, 4(2) : 158-178. 10.14203/beritabiologi.v15i1.2 861

Roohi, Z., Imanpoor, M. R. 2015. The Efficacy of The Oils Of Spearmint and Methyl Salicylate as New Anesthetics And Their Effect on Glucose Levels In Common Carp (Cyprinus carpio L. 1758) Juveniles. Aquaculture, 437: 327-332. 10.1016/j.aquaculture.2014.12. 019

Saskia, Y., Esti, H., Tutik, K. 2013. Toksisitas dan Kemampuan Anestetik Minyak Cengkeh (Sygnium aromaticum) Terhadap Benih Ikan Pelangi Merah (Glossolepis incisus). Jurnal Ilmu Perikanan dan Sumberdaya Perairan, 2(1): 84-88.

Saputra A., Setianingsih, L., Yosmaniar., Prihadi, T.H. 2017. Distribusi Nitrogen Dan Fosfor Pada Budidaya Ikan Gabus (Channa striata) dan Probiotik. Jurnal Riset Akuakultur 12: $379-388$. http://dx.doi.org/10.15578/jra.1 2.4.2017.379-388

Saputra, F., Sukardi, E.S., Mahendra. 2017. Efektifitas Konsentrasi Ekstrak Rebung Bambu (Gigantochloa nigrociliata) Sebagai Anestesi Terhadap Kelangsungan Hidup Benih Ikan Lele Sangkuriang (Clarias gariepinus). Jurnal Akuakultura, 1(1): 9-18. https://doi.org/ $\underline{10.35308 / j a . v 1 i 1.476}$

Seeman, P. 1967. Transient Holes in The Erythrocyte Membrane During Hypotonic Hemolysis and Stable in The Membrane After Lysis by Saponin and Lysolechitin. The Journal of Cell Biology, 32 : $55-70$. https://doi.org/10.1083/jcb.32.1 .55

Septiarusli, E.I., Kiki, H., Yenny, M., Danar, D. 2012. Potensi Senyawa Metabolit Sekunder Dari Ekstrak Biji Buah Keben (Barringtonia asiatica) dalam Proses Anestesi Ikan Kerapu Macan (Ephinephelus fuscogut- 
tatus). Jurnal Perikanan dan Kelautan, 3(3): 295-299.

Soedibya, P.H.T., dan Pramono, T.B. 2018. Budidaya Air Tawar. Universitas Jenderal Soedirman : Purwokerto. 70 hal.

Stoskopf, M.K. 1993. Fish Medicine. W.B Saunders Company. Mexico. Hal. 79 - 112.

Sukarsa, D. 2005. Penerapan Teknik Imotilisasi Menggunakan Ekstrak Alga Laut (Caulerpa sertularioides) dalam Transportasi Ikan Kerapu (Epinephelus Suillus) Hidup Tanpa Media Air. Buletin Teknologi Hasil Perikanan, 3(1): 12-24. https://doi.org/10.17844/jphpi. v8i1.1023

Sulmartiwi, L., Harweni, T., Mukti, A.T., Triastuti, J.R. 2013. Pengaruh Penggunaan Larutan Daun Bandotan (Ageratum conyzoides) Terhadap Kadar Glukosa Darah Ikan Koi (Cyprinus carpio) Pasca Transportasi. Jurnal Ilmiah Perikanan dan Kelautan, 5(1): 73-76.

Suwandi, R., Nugraha, R., Zulfamy, K.E. 2013. Aplikasi Ekstrak Daun Jambu (Psidium guajava var. Pomifera) Pada Proses Transportasi Ikan Nila (Oreochromis niloticus). Jurnal Pengolahan Hasil Perikanan Indonesia, 16(1): 69-78.

Theinpoint, D. and Niemegeers, C.J.E. 1965. 7464- a new potenet anesthetics in fish. International Zoo. Yearbook, 5: 202-205.

Teixeira, N.D.S., Marques, L.S., Rodrigues, R.B., Gusso, D., Fossati, A.A.N., Streit Jr., D.P. 2019. Effects of Anesthetic Tricaine on Stress And Reproductive Aspects of South American Silver Catfish (Rhamdia quelen) male. Animal Science Research Program of Federal University of Rio Grande do Sul

Temitope, J. 2014. Anaesthetic Potential of Tobacco (Nicotiana tobaccum) on Clarias gariepinus (Burchell 1822) Fingerlings. Journal of Agricultural Science, 6(5): 8690. http://dx.doi.org/10.5539/ jas.v6n5p86

Velisek, J., Lepic, P., Stara, A., Turek, J., Kozak, P. 2014. The Effects of Four Anaesthetics on Haematological and Blood Biochemical Profiles In Vimba Bream, Vimba Vimba. Veterinarni Medicina, 59(2) : 8187.https://doi.org/10.17221/73 17-VETMED

Zulfamy, K.E. 2013. Aplikasi Ekstrak Daun Jambu Biji Daging Buah Merah (Psidium guajava Var. Pomifera) Pada Proses Transportasi Ikan Nila (Oreochromis niloticus). Skripsi, Fakultas Perikanan Dan Ilmu Kelautan, Institut Pertanian Bogor. 38 hal. 